Article

\title{
Structure-Activity Relationship of Halophenols as a New Class of Protein Tyrosine Kinase Inhibitors
}

\author{
Xiu E Feng ${ }^{1,2}$, Wan Yi Zhao ${ }^{1}$, Shu Rong Ban ${ }^{1}$, Cheng Xiao Zhao ${ }^{1}$, Qing Shan Li ${ }^{1,2,3, *}$ \\ and Wen Han Lin ${ }^{3}$
}

1 School of Pharmaceutical Science, Shanxi Medical University, Taiyuan 030001, Shanxi, China; E-Mails: xiuefeng@163.com (X.E.F.); zhaowanyi@yahoo.cn (W.Y.Z.); shurongban@163.com (S.R.B.); zhaochengxiao1982@163.com (C.X.Z.)

2 School of Public Health, Shanxi Medical University, Taiyuan 030001, Shanxi, China

3 State Key Laboratory of Natural and Biomimetic Drugs, Peking University, Beijing 100083, China; E-Mail:whlin@bjmu.edu.cn

* Author to whom correspondence should be addressed; E-Mail: qingshanl@yahoo.com; Tel.: +86-351-4690322; Fax: +86-351-4690322.

Received: 25 May 2011; in revised form: 14 September 2011 / Accepted: 15 September 2011 / Published: 19 September 2011

\begin{abstract}
A series of new benzophenone and diphenylmethane halophenol derivatives were prepared. Their structures were established based on ${ }^{1} \mathrm{H}$ NMR, ${ }^{13} \mathrm{C}$ NMR and HRMS data. All prepared compounds were screened for their in vitro protein tyrosine kinase (PTK) inhibitory activities. The effects of modification of the linker, functional groups and substituted positions at the phenyl ring on PTK inhibitory activity were investigated. Twelve halophenols showed significant PTK inhibitory activity. Among them, compounds $\mathbf{6 c}, \mathbf{6 d}$, 7d, 9d, 10d, 11d and 13d exhibited stronger activities than that of genistein, the positive reference compound. The results gave a relatively full and definite description of the structure-activity relationship and provided a foundation for further design and structure optimization of the halophenols.
\end{abstract}

Keywords: protein tyrosine kinase; halophenol; structure-activity relationship; benzophenone; diphenylmethane 


\section{Introduction}

Protein tyrosine kinases (PTKs), which are members of a large family of oncoproteins and proto-oncoproteins, play a major role in mitogenic signal transduction, and are involved in the control of cell proliferation, differentiation and transformation. Continuing activation of PTK is associated with proliferative disorders such as cancer; hence, PTK inhibitors have been developed as molecular-targeting cancer therapeutic agents. The discovery and development of PTK inhibitors as new cancer therapeutic agents have now attracted much attention [1-9]. To date, many PTK inhibitors with potent activities have already passed or are currently in clinical trials to investigate their applicability as anti-cancer drugs [10].

Various structural halophenols isolated from biologically active natural products such as various marine algae, ascidians and sponges present a wide spectrum of bioactivities including protein tyrosine phosphatase (PTP1B) inhibitory [11], antioxidative [12,13], antithrombotic [14], antimicrobial [15,16], anti-inflammatory [17], enzyme inhibitory [18], cytotoxic [19], and appetite suppressant [20], PTK inhibitory activities [21]. However, to the best of our knowledge, very little is known about the inhibitory activity of benzophenone and diphenylmethane halophenols against PTK, and their corresponding structure-activity relationships (SARs) have been rarely reported, despite the fact that several natural diphenylmethane bromophenols isolated from the brown alga Leathesia nana have been reported to show moderate inhibitory activity against PTK with over-expression of c-kit [21], which reveals that diphenylmethane halophenols may possess potential significant PTK inhibitory activity.

We therefore designed and synthesized a series of new diphenylmethane and benzophenone halophenol derivatives by modification of the linker (illustrated in Table 1), functional groups, and substituted positions at the phenyl ring to find novel structural halophenol derivatives with strong PTK inhibitory activity, and tried to establish the SAR on the basis of this new compound library. In our previous study [22], a series of bromo- and chloro- substituted halophenols were reported for their significant in vitro antioxidative and cytoprotective activities. However, the PTK inhibitory activity has not been evaluated. In the continued efforts towards discovering potent PTK inhibitors, a series of new fluoro- and iodo- functionalized benzophenone and diphenylmethane halophenols derivatives were also prepared and screened for their in vitro PTK inhibitory activity with genistein as positive control [23,24], in accordance with the fact that inclusion of F or I atoms in a compound may have profound effects on drug disposition [25-30]. The results provide some clear and useful information about recognition of the SAR.

\section{Results and Discussion}

\subsection{Chemistry}

A series of new benzophenone and diphenylmethane halophenol derivatives with several groups substituted at different positions on the phenyl ring were synthesized to determine how the substituents affect the PTK inhibitory activity. Halophenol compounds $\mathbf{5 c - 1 3 c}$ and $\mathbf{5 d - 1 3 d}$ were prepared in our previous study [22]. In the present study, 12 fluoro- and four iodo- functionalized halophenol 
derivatives (1a-4d) were also prepared (Scheme 1), including 11 new compounds $\mathbf{1 b}, \mathbf{1 c}, \mathbf{1 d}, \mathbf{2 b}, \mathbf{2 c}$, 2d, 3b, 3d, 4b, 4c and 4d.

Scheme 1. Synthesis of benzophenone and diphenylmethane halophenol derivatives. Reagents and conditions: (a) $\mathrm{AlCl}_{3} / \mathrm{CH}_{2} \mathrm{Cl}_{2}$, rt, 4 h; (b) $\mathrm{LiAlH}_{4} / \mathrm{AlCl}_{3} /$ ether, $40^{\circ} \mathrm{C}$, refluxed for $2 \mathrm{~h}$; (c) $\mathrm{BBr}_{3} / \mathrm{CH}_{2} \mathrm{Cl}_{2}(1 / 9, \mathrm{v} / \mathrm{v})$ was added to the solution at $-78{ }^{\circ} \mathrm{C}$, warmed to room temperature and stirred for $2 \mathrm{~h}$.

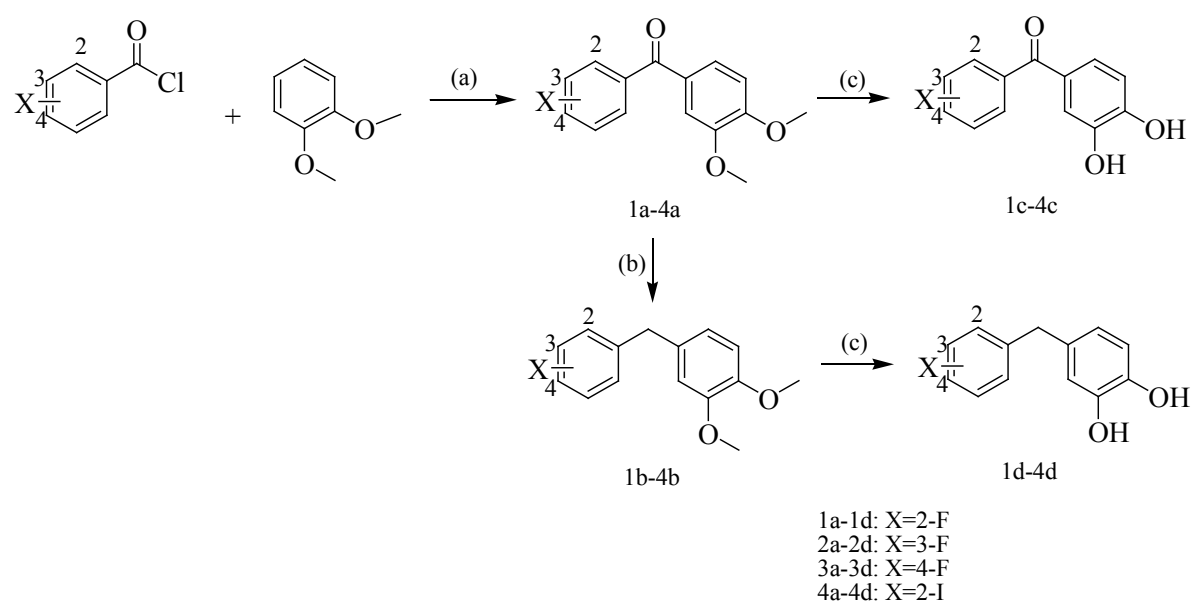

\subsection{In vitro PTK Inhibitory Activity}

The in vitro PTK inhibitory activity of the prepared compounds listed in Table 1 was tested by ELISA with genistein as a positive reference compound. As shown in Table 1, 12 halophenols exhibited strong activities, which in some cases, were identical to, or even higher than, that of genistein in the same model. Among these, seven compounds, 6c, 6d, 7d, 9d, 10d, 11d and 13d, showed the strongest activities with $\mathrm{IC}_{50}$ values of $2.97-12.9 \mu \mathrm{M}$, which were stronger than that of genistein with an $\mathrm{IC}_{50}$ value of $13.6 \mu \mathrm{M}$. Compound 8d with an $\mathrm{IC}_{50}$ value of $14.8 \mu \mathrm{M}$ exhibited identical activity to genistein. Compounds $8 \mathbf{c}, 9 \mathbf{c}$ and $11 \mathbf{c}$ showed lower activities with $\mathrm{IC}_{50}$ values of $17.7,17.8$ and $16.0 \mu \mathrm{M}$, respectively. Compound $10 \mathrm{c}$ exhibited weak activity with an $\mathrm{IC}_{50}$ of $41.6 \mu \mathrm{M}$.

Table 1. Structures and in vitro protein tyrosine kinase (PTK) inhibitory activities of the prepared halophenols. PTK activity was determined by the ELISA method with genistein as positive control.<smiles>[R9]c1c(Br)cc(C=Cc2c(Br)c(Br)c(Br)c(Br)c2Br)c(Br)c1Br</smiles>

\begin{tabular}{|c|c|c|c|c|c|c|c|c|c|c|c|}
\hline \multirow{2}{*}{ Compd. } & \multicolumn{10}{|c|}{ Substituted group } & \multirow{2}{*}{$\begin{array}{l}\mathrm{IC}_{50}{ }^{\mathrm{a}} \\
(\mu \mathrm{M})\end{array}$} \\
\hline & Linker & $\mathbf{R}_{1}$ & $\mathbf{R}_{2}$ & $\mathbf{R}_{\mathbf{3}}$ & $\mathbf{R}_{\mathbf{4}}$ & $\mathbf{R}_{5}$ & $\mathbf{R}_{6}$ & $\mathbf{R}_{7}$ & $\mathbf{R}_{8}$ & $\mathbf{R}_{\mathbf{9}}$ & \\
\hline $1 c^{*}$ & $\mathrm{C}=\mathrm{O}$ & $\mathrm{F}$ & $\mathrm{H}$ & $\mathrm{H}$ & $\mathrm{H}$ & $\mathrm{H}$ & $\mathrm{H}$ & $\mathrm{H}$ & $\mathrm{OH}$ & $\mathrm{OH}$ & $>50$ \\
\hline $1 d *$ & $\mathrm{CH}_{2}$ & $\mathrm{~F}$ & $\mathrm{H}$ & $\mathrm{H}$ & $\mathrm{H}$ & $\mathrm{H}$ & $\mathrm{H}$ & $\mathrm{H}$ & $\mathrm{OH}$ & $\mathrm{OH}$ & $>50$ \\
\hline $2 \mathrm{c} *$ & $\mathrm{C}=\mathrm{O}$ & $\mathrm{H}$ & $\mathrm{F}$ & $\mathrm{H}$ & $\mathrm{H}$ & $\mathrm{H}$ & $\mathrm{H}$ & $\mathrm{H}$ & $\mathrm{OH}$ & $\mathrm{OH}$ & $>50$ \\
\hline
\end{tabular}


Table 1. Cont.

\begin{tabular}{|c|c|c|c|c|c|c|c|c|c|c|c|}
\hline \multirow[t]{2}{*}{ Compd. } & \multicolumn{10}{|c|}{ Substituted group } & \multirow{2}{*}{$\begin{array}{l}\mathrm{IC}_{50}{ }^{\mathrm{a}} \\
(\mu \mathrm{M})\end{array}$} \\
\hline & Linker & $\mathbf{R}_{1}$ & $\mathbf{R}_{2}$ & $\mathbf{R}_{\mathbf{3}}$ & $\mathbf{R}_{4}$ & $\mathbf{R}_{\mathbf{5}}$ & $\mathbf{R}_{6}$ & $\mathbf{R}_{7}$ & $\mathbf{R}_{8}$ & $\mathbf{R}_{9}$ & \\
\hline $2 d^{*}$ & $\mathrm{CH}_{2}$ & $\mathrm{H}$ & $\mathrm{F}$ & $\mathrm{H}$ & $\mathrm{H}$ & $\mathrm{H}$ & $\mathrm{H}$ & $\mathrm{H}$ & $\mathrm{OH}$ & $\mathrm{OH}$ & $>50$ \\
\hline $3 c$ & $\mathrm{C}=\mathrm{O}$ & $\mathrm{H}$ & $\mathrm{H}$ & $\mathrm{F}$ & $\mathrm{H}$ & $\mathrm{H}$ & $\mathrm{H}$ & $\mathrm{H}$ & $\mathrm{OH}$ & $\mathrm{OH}$ & $>50$ \\
\hline $3 d^{*}$ & $\mathrm{CH}_{2}$ & $\mathrm{H}$ & $\mathrm{H}$ & $\mathrm{F}$ & $\mathrm{H}$ & $\mathrm{H}$ & $\mathrm{H}$ & $\mathrm{H}$ & $\mathrm{OH}$ & $\mathrm{OH}$ & $>50$ \\
\hline $4 \mathrm{c} *$ & $\mathrm{C}=\mathrm{O}$ & I & $\mathrm{H}$ & $\mathrm{H}$ & $\mathrm{H}$ & $\mathrm{H}$ & $\mathrm{H}$ & $\mathrm{H}$ & $\mathrm{OH}$ & $\mathrm{OH}$ & $>50$ \\
\hline $4 d *$ & $\mathrm{CH}_{2}$ & I & $\mathrm{H}$ & $\mathrm{H}$ & $\mathrm{H}$ & $\mathrm{H}$ & $\mathrm{H}$ & $\mathrm{H}$ & $\mathrm{OH}$ & $\mathrm{OH}$ & $>50$ \\
\hline $5 c$ & $\mathrm{C}=\mathrm{O}$ & $\mathrm{Br}$ & $\mathrm{OH}$ & $\mathrm{OH}$ & $\mathrm{OH}$ & $\mathrm{Br}$ & $\mathrm{H}$ & $\mathrm{H}$ & $\mathrm{OH}$ & $\mathrm{OH}$ & $>50$ \\
\hline $5 d$ & $\mathrm{CH}_{2}$ & $\mathrm{Br}$ & $\mathrm{OH}$ & $\mathrm{OH}$ & $\mathrm{OH}$ & $\mathrm{Br}$ & $\mathrm{H}$ & $\mathrm{H}$ & $\mathrm{OH}$ & $\mathrm{OH}$ & $>50$ \\
\hline $6 c$ & $\mathrm{C}=\mathrm{O}$ & $\mathrm{Cl}$ & $\mathrm{OH}$ & $\mathrm{OH}$ & $\mathrm{OH}$ & $\mathrm{Cl}$ & $\mathrm{H}$ & $\mathrm{H}$ & $\mathrm{OH}$ & $\mathrm{OH}$ & 2.97 \\
\hline $6 \mathrm{~d}$ & $\mathrm{CH}_{2}$ & $\mathrm{Cl}$ & $\mathrm{OH}$ & $\mathrm{OH}$ & $\mathrm{OH}$ & $\mathrm{Cl}$ & $\mathrm{H}$ & $\mathrm{H}$ & $\mathrm{OH}$ & $\mathrm{OH}$ & 3.96 \\
\hline $7 \mathrm{c}$ & $\mathrm{C}=\mathrm{O}$ & $\mathrm{H}$ & $\mathrm{Br}$ & $\mathrm{OH}$ & $\mathrm{H}$ & $\mathrm{H}$ & $\mathrm{Br}$ & $\mathrm{H}$ & $\mathrm{OH}$ & $\mathrm{OH}$ & $>50$ \\
\hline $7 d$ & $\mathrm{CH}_{2}$ & $\mathrm{H}$ & $\mathrm{Br}$ & $\mathrm{OH}$ & $\mathrm{H}$ & $\mathrm{H}$ & $\mathrm{Br}$ & $\mathrm{H}$ & $\mathrm{OH}$ & $\mathrm{OH}$ & 6.34 \\
\hline $8 c$ & $\mathrm{C}=\mathrm{O}$ & $\mathrm{Cl}$ & $\mathrm{H}$ & $\mathrm{H}$ & $\mathrm{H}$ & $\mathrm{H}$ & $\mathrm{H}$ & $\mathrm{H}$ & $\mathrm{OH}$ & $\mathrm{OH}$ & 17.7 \\
\hline $8 d$ & $\mathrm{CH}_{2}$ & $\mathrm{Cl}$ & $\mathrm{H}$ & $\mathrm{H}$ & $\mathrm{H}$ & $\mathrm{H}$ & $\mathrm{H}$ & $\mathrm{H}$ & $\mathrm{OH}$ & $\mathrm{OH}$ & 14.8 \\
\hline $9 \mathrm{c}$ & $\mathrm{C}=\mathrm{O}$ & $\mathrm{H}$ & $\mathrm{Cl}$ & $\mathrm{H}$ & $\mathrm{H}$ & $\mathrm{H}$ & $\mathrm{H}$ & $\mathrm{H}$ & $\mathrm{OH}$ & $\mathrm{OH}$ & 17.8 \\
\hline $9 d$ & $\mathrm{CH}_{2}$ & $\mathrm{H}$ & $\mathrm{Cl}$ & $\mathrm{H}$ & $\mathrm{H}$ & $\mathrm{H}$ & $\mathrm{H}$ & $\mathrm{H}$ & $\mathrm{OH}$ & $\mathrm{OH}$ & 12.9 \\
\hline $10 \mathrm{c}$ & $\mathrm{C}=\mathrm{O}$ & $\mathrm{H}$ & $\mathrm{H}$ & $\mathrm{Cl}$ & $\mathrm{H}$ & $\mathrm{H}$ & $\mathrm{H}$ & $\mathrm{H}$ & $\mathrm{OH}$ & $\mathrm{OH}$ & 41.6 \\
\hline $10 \mathrm{~d}$ & $\mathrm{CH}_{2}$ & $\mathrm{H}$ & $\mathrm{H}$ & $\mathrm{Cl}$ & $\mathrm{H}$ & $\mathrm{H}$ & $\mathrm{H}$ & $\mathrm{H}$ & $\mathrm{OH}$ & $\mathrm{OH}$ & 6.97 \\
\hline $11 \mathrm{c}$ & $\mathrm{C}=\mathrm{O}$ & $\mathrm{H}$ & $\mathrm{H}$ & $\mathrm{H}$ & $\mathrm{H}$ & $\mathrm{H}$ & $\mathrm{Br}$ & $\mathrm{H}$ & $\mathrm{OH}$ & $\mathrm{OH}$ & 16.0 \\
\hline $11 d$ & $\mathrm{CH}_{2}$ & $\mathrm{H}$ & $\mathrm{H}$ & $\mathrm{H}$ & $\mathrm{H}$ & $\mathrm{H}$ & $\mathrm{Br}$ & $\mathrm{H}$ & $\mathrm{OH}$ & $\mathrm{OH}$ & 6.26 \\
\hline $12 \mathrm{c}$ & $\mathrm{C}=\mathrm{O}$ & $\mathrm{H}$ & $\mathrm{H}$ & $\mathrm{H}$ & $\mathrm{H}$ & $\mathrm{H}$ & $\mathrm{Br}$ & $\mathrm{Br}$ & $\mathrm{OH}$ & $\mathrm{OH}$ & $>50$ \\
\hline $12 d$ & $\mathrm{CH}_{2}$ & $\mathrm{H}$ & $\mathrm{H}$ & $\mathrm{H}$ & $\mathrm{H}$ & $\mathrm{H}$ & $\mathrm{Br}$ & $\mathrm{Br}$ & $\mathrm{OH}$ & $\mathrm{OH}$ & $>50$ \\
\hline $13 c$ & $\mathrm{C}=\mathrm{O}$ & $\mathrm{OH}$ & $\mathrm{H}$ & $\mathrm{H}$ & $\mathrm{Br}$ & $\mathrm{H}$ & $\mathrm{Br}$ & $\mathrm{H}$ & $\mathrm{OH}$ & $\mathrm{OH}$ & $>50$ \\
\hline $13 d$ & $\mathrm{CH}_{2}$ & $\mathrm{OH}$ & $\mathrm{H}$ & $\mathrm{H}$ & $\mathrm{Br}$ & $\mathrm{H}$ & $\mathrm{Br}$ & $\mathrm{H}$ & $\mathrm{OH}$ & $\mathrm{OH}$ & 5.05 \\
\hline $\begin{array}{l}\text { Control } \\
\text { (Genistein) }\end{array}$ & & & & & & & & & & & 13.6 \\
\hline
\end{tabular}

* New compound; ${ }^{\mathrm{a}}$ The $\mathrm{IC}_{50}$ values were determined in triplicate.

\subsection{SAR Analysis}

Diphenylmethane halophenols $\mathbf{7 d}, \mathbf{8 d}, \mathbf{9 d}, \mathbf{1 0 d}, \mathbf{1 1 d}$ and 13d displayed higher activities with $\mathrm{IC}_{50}$ values of $6.34,14.8,12.9,6.97,6.26$ and $5.05 \mu \mathrm{M}$ than those of corresponding benzophenone halophenols 7c, 8c, 9c, 10c, 11c and 13c. Bromophenols 7c and 13c, which are isomers, showed no activity. Isomers of chlorophenols $8 \mathbf{c}, 9 \mathbf{c}, 10 \mathbf{c}$ and bromophenol 11c exhibited moderate activity with $\mathrm{IC}_{50}$ values of $17.7,17.8,41.6$ and $16.0 \mu \mathrm{M}$, respectively. Replacement of the methylene group by a carbonyl group, except $\mathbf{6 c}$ which showed similar activity to $\mathbf{6 d}$, led to an obvious decrease, even complete disappearance of the activity, which suggested that the methylene group may greatly contribute to the PTK inhibitory activity.

Meanwhile, substitution of the hydroxyl groups by methoxyl groups resulted in the disappearance of activity, and indeed, none of the compounds with methoxyl groups on the phenyl ring showed any activity with $\mathrm{IC}_{50}$ value higher than $50 \mu \mathrm{M}$. This indicated that the methoxyl group exerted a great negative effect on the PTK inhibitory activity, and also illustrated that the hydroxyl groups were 
essential. It is implied that these active halophenols as hydrogen donors could have key interactions with PTK.

By comparing the activities of the halogen-substituted compounds $\mathbf{5 c}, \mathbf{6 c}, \mathbf{5 d}$ and $\mathbf{6 d}$, which possessed five hydroxyls and two halogen atoms at the same positions, we found that the chlorophenol compounds $\mathbf{6 c}$ and $\mathbf{6 d}$ exhibited the strongest activities with $\mathrm{IC}_{50}$ values of $2.97 \mu \mathrm{M}$ and $3.96 \mu \mathrm{M}$, respectively. However, the bromophenols 5c and 5d showed no activity. Moreover, for all of the fluoro- and iodo- functionalized halophenols, no activity was observed. Hence, the halogen atoms on the phenyl ring contributed to the activity in the order of $\mathrm{Cl}>\mathrm{Br}>\mathrm{F}$ (or I), which suggested that the chloro atom may play a pivotal role between the interaction of active halophenols and PTK. The results also showed that an increased number of hydroxyl groups and chloro atoms may be beneficial to the activity.

Compounds $8 \mathbf{c}$ and $9 \mathbf{c}$ with a chloro atom at the ortho- and meta- position of the carbonyl group exhibited moderate activities, with $\mathrm{IC}_{50}$ values of $17.7 \mu \mathrm{M}$ and $17.8 \mu \mathrm{M}$, respectively. Compound 10c with a chloro atom at the para-position of the carbonyl group showed weak activity, with an $\mathrm{IC}_{50}$ value of $41.6 \mu \mathrm{M}$. Compounds $\mathbf{1 0 d}$ and $9 \mathrm{~d}$, with a chloro atom at the para- and meta- position of the methene group, showed high activities with $\mathrm{IC}_{50}$ values of $6.97 \mu \mathrm{M}$ and $12.9 \mu \mathrm{M}$, respectively. Compound 8d with a chloro atom at the ortho-position of the methene group exhibited identical activity with an $\mathrm{IC}_{50}$ value of $14.8 \mu \mathrm{M}$, compared to that of the positive control compound $\left(\mathrm{IC}_{50}=13.6 \mu \mathrm{M}\right)$. To the isomers of these chlorophenols, the chloro atom substituted at different position on the phenyl ring had significant effects on the activity. In addition, the same substituted position of the chloro atom on the phenyl ring had an entirely different effect on the activity of benzophenone and diphenylmethane halophenols. The results indicated that the linker and halogen had a combined influence on the activity.

The activities of compounds $12 \mathrm{c}$ and $\mathbf{1 2 d}$ were not enhanced by the increased number of halogen atoms. The bromophenols 11c and 11d substituted by one bromo atom obviously showed better activities than those of bromophenols $\mathbf{1 2 c}$ and $\mathbf{1 2 d}$ with two bromo atoms at the same phenyl ring.

\section{Experimental Section}

\subsection{General}

Melting points were taken on a micromelting point apparatus, which were uncorrected. ${ }^{1} \mathrm{H}$ and ${ }^{13} \mathrm{C}$ NMR spectra were recorded with a Bruker-AV 400 spectrometer at 400 and $100 \mathrm{MHz}$ respectively, in $\mathrm{CDCl}_{3}, \mathrm{DMSO}-d_{6}$ or $\mathrm{CD}_{3} \mathrm{OD}$ with TMS as reference. Chemical shifts ( $\delta$ values) and coupling constants ( $J$ values) were given in ppm and $\mathrm{Hz}$, respectively. ESI mass spectra were obtained on an API QTRAP 3200 MS spectrometer, and HRMS were recorded on a Bruker Daltonics Apex IV 70e FTICR-MS (Varian 7.0T).

Ether was distilled from sodium benzophenone ketyl. Dichloromethane was distilled from calcium hydride. Other reagents and solvents were commercially available unless otherwise indicated. 


\subsection{Typical Procedures for the Preparation of Halophenol Derivatives}

The general procedures for compounds $\mathbf{5 c - 1 3 c}$, and $\mathbf{5 d - 1 3 d}$ have been reported in our earlier study [22]. A series of new fluoro- and iodo- functionalized compounds were prepared according to the following general procedures.

\subsubsection{Preparation of compounds $\mathbf{1 a}-\mathbf{4 a}$}

2-fluoro-3',4'-dimethoxyl benzophenone (1a): 2-Fluorobenzoyl chloride (10 mL, $82.2 \mathrm{mmol})$ was added at $0{ }^{\circ} \mathrm{C}$ to a solution that contained 1,2-dimethoxybenzene $(10 \mathrm{~mL}, 78.5 \mathrm{mmol})$ in dried $\mathrm{CH}_{2} \mathrm{Cl}_{2}$ $(60 \mathrm{~mL})$. Anhydrous $\mathrm{AlCl}_{3}(11.1 \mathrm{~g}, 83.2 \mathrm{mmol})$ was added by portion wise. The mixture was allowed to warm to room temperature and stirred for $4 \mathrm{~h}$, then ice-water $(100 \mathrm{~mL})$ was added to the mixture. The organic phase was separated, washed with water $(50 \mathrm{~mL})$ and dried over anhydrous $\mathrm{Na}_{2} \mathrm{SO}_{4}$. The solvent was evaporated under reduced pressure, and the crude product was recrystallized from methanol to give compound $\mathbf{1 a}$ as a white powder in $73 \%$ yield. m.p. $77-79{ }^{\circ} \mathrm{C} ;{ }^{1} \mathrm{H} \mathrm{NMR}\left(\mathrm{CDCl}_{3}\right) \delta$ : $7.58(\mathrm{~d}, 1 \mathrm{H}, \mathrm{Ph}-6-\mathrm{H}), 7.15-7.55(\mathrm{~m}, 5 \mathrm{H}, \mathrm{PhH}), 6.90$ (d, 1H, Ph-5'-H), 3.97 (s, 3H, OCH $)^{2}$, $3.96\left(\mathrm{~s}, 3 \mathrm{H}, \mathrm{OCH}_{3}\right) ;{ }^{13} \mathrm{C} \mathrm{NMR}\left(\mathrm{CDCl}_{3}\right) \delta: 192.0,161.0,158.5,153.8,149.1,132.5,132.4,130.5,130.4$, $130.3,127.5,127.4,125.9,124.2,124.1,116.3,116.1,111.0,109.9,56.1,56.0$; MS (ESI) $m / z: 261.0$ $\left([\mathrm{M}+\mathrm{H}]^{+}, 100\right)$.

Compounds $\mathbf{2 a}-\mathbf{4 a}$ were prepared in the similar manner as described for $\mathbf{1 a}$.

3-fluoro-3',4'-dimethoxyl benzophenone (2a): White powder, Yield $80 \%$, mp $103-105{ }^{\circ} \mathrm{C}$; ${ }^{1} \mathrm{H}$ NMR $\left(\mathrm{CDCl}_{3}\right) \delta: 7.46-7.56$ (m, 4H, Ph-2,4,5,6-H), 7.39 (dd, $J=2.0,8.4 \mathrm{~Hz}, 1 \mathrm{H}, \mathrm{Ph}-6$ '- $\left.\mathrm{H}\right), 7.26-7.30(\mathrm{~m}, 1 \mathrm{H}$, Ph-2'-H), 6.93 (d, $J=8.4 \mathrm{~Hz}, 1 \mathrm{H}, \mathrm{Ph}-5$ '-H), $3.96\left(\mathrm{~s}, 3 \mathrm{H}, \mathrm{OCH}_{3}\right), 3.98\left(\mathrm{~s}, 3 \mathrm{H}, \mathrm{OCH}_{3}\right) ;{ }^{13} \mathrm{C} \mathrm{NMR}$ $\left(\mathrm{CDCl}_{3}\right) \delta: 194.1,163.6,161.2,153.3,149.2,140.4,140.3,129.9,129.8,129.6,125.6,125.4,118.9$, 118.7, 116.6, 116.4, 112.0, 109.8, 56.1, 56.1; MS (ESI) $m / z: 261.0\left([\mathrm{M}+\mathrm{H}]^{+}, 100\right)$.

4-fluoro-3',4'-dimethoxyl benzophenone (3a): White powder, Yield 86\%, mp 101-103 ${ }^{\circ} \mathrm{C}$; ${ }^{1} \mathrm{H}$ NMR

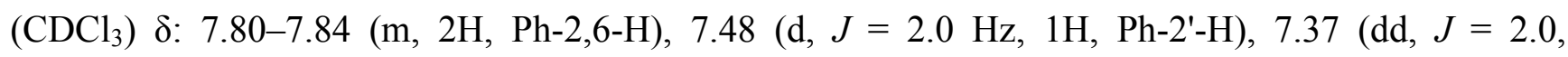
$8.4 \mathrm{~Hz}, 1 \mathrm{H}, \mathrm{Ph}-6$ '-H), 7.15-7.19 (m, 2H, Ph-3,5-H), 6.93 (d, J = 8.4 Hz, 1H, Ph-5'-H), 3.98 (s, 3H, $\left.\mathrm{OCH}_{3}\right), 3.96\left(\mathrm{~s}, 3 \mathrm{H}, \mathrm{OCH}_{3}\right) ;{ }^{13} \mathrm{C} \mathrm{NMR}\left(\mathrm{CDCl}_{3}\right) \delta: 194.2,166.3,163.8,153.1,149.1,134.4,132.3$, 132.2, 130.1, 125.2, 115.4, 115.2, 112.1, 109.8, 56.1, 56.0; MS (ESI) $m / z: 261.0\left([\mathrm{M}+\mathrm{H}]^{+}, 100\right)$.

2-iodo-3',4'-dimethoxyl benzophenone (4a): White powder, Yield 85\%, mp $143-145{ }^{\circ} \mathrm{C}$; ${ }^{1} \mathrm{H}$ NMR $\left(\mathrm{CDCl}_{3}\right) \delta: 7.93$ (d, $\left.J=8.0 \mathrm{~Hz}, 1 \mathrm{H}, \mathrm{Ph}-3-\mathrm{H}\right), 7.60$ (d, $\left.J=2.0 \mathrm{~Hz}, 1 \mathrm{H}, \mathrm{Ph}-6-\mathrm{H}\right), 7.45$ (m, 1H, Ph-5-H), 7.31 (dd, $J=2.0,8.0 \mathrm{~Hz}, 1 \mathrm{H}, \mathrm{Ph}-4-\mathrm{H}), 7.16-7.21$ (m, 2H, Ph-2', $\left.6^{\prime}-\mathrm{H}\right), 6.86$ (d, $\left.J=8.4 \mathrm{~Hz}, 1 \mathrm{H}, \mathrm{Ph}-5^{\prime}-\mathrm{H}\right)$, $3.96\left(\mathrm{~s}, 3 \mathrm{H}, \mathrm{OCH}_{3}\right), 3.95\left(\mathrm{~s}, 3 \mathrm{H}, \mathrm{OCH}_{3}\right) ;{ }^{13} \mathrm{C} \mathrm{NMR}\left(\mathrm{CDCl}_{3}\right) \delta: 196.1,154.0,149.4,144.7,139.5,130.9$, 128.6, 128.2, 127.7, 126.8, 111.1, 109.9, 92.4, 56.2, 56.1; MS (ESI) $m / z: 369.0\left([\mathrm{M}+\mathrm{H}]^{+}, 100\right)$.

\subsubsection{The Preparation of Compounds $\mathbf{1 b}-\mathbf{4 b}$}

2-fluoro-3',4'-dimethoxyl diphenylmethane (1b): Anhydrous $\mathrm{AlCl}_{3}(2.00 \mathrm{~g}, 15.0 \mathrm{mmol})$ and $\mathrm{LiAlH}_{4}$ $(1.00 \mathrm{~g}, 26.4 \mathrm{mmol})$ were slowly added to dried ether $(50 \mathrm{~mL})$. After stirring for $5 \mathrm{~min}$, compound 1a $(2.00 \mathrm{~g}, 7.69 \mathrm{mmol})$ was dissolved in dried ether $(10 \mathrm{~mL})$ and dropwisely added to the solution. The mixture was warmed to $40{ }^{\circ} \mathrm{C}$, refluxed for $2 \mathrm{~h}$, then cooled and quenched with $50 \mathrm{~mL} 18 \%$ aqueous 
$\mathrm{HCl}$. The organic phase was separated. The water layer was extracted twice with ethyl acetate $(2 \times 30 \mathrm{~mL})$. The combined organics were washed to neutral with water, dried over anhydrous $\mathrm{Na}_{2} \mathrm{SO}_{4}$, and then concentrated via rotary evaporation. The crude product was purified by silica gel chromatography with ethyl acetate-petroleum ether (1/9) as eluent to afford compound $\mathbf{1 b}$. The product was recrystallized from methanol to give a white powder in $40 \%$ yield. mp $51-52{ }^{\circ} \mathrm{C}$; ${ }^{1} \mathrm{H}$ NMR $\left(\mathrm{CDCl}_{3}\right)$ 8: 7.04-7.24 (m, 4H, Ph-3,4,5,6-H), 6.77-6.84 (m, 3H, Ph-2',5',6'-H), 3.97 (s, 2H, $\left.\mathrm{CH}_{2}\right), 3.88$ $\left(\mathrm{s}, 3 \mathrm{H}, \mathrm{OCH}_{3}\right), 3.87\left(\mathrm{~s}, 3 \mathrm{H}, \mathrm{OCH}_{3}\right) ;{ }^{13} \mathrm{C} \mathrm{NMR}\left(\mathrm{CDCl}_{3}\right) \delta: 162.1,159.7,149.0,147.5,132.4,130.9$, $130.8,128.4,128.3,127.9,127.8,124.1,124.0,120.8,115.4,115.2,112.1,111.2,55.9,55.8,34.4$; MS (ESI) $m / z: 247.0\left([\mathrm{M}+\mathrm{H}]^{+}, 100\right)$.

Compounds $\mathbf{2 b - 4 b}$ were prepared in the similar manner as described for $\mathbf{1 b}$.

3-fluoro-3',4'-dimethoxyl diphenylmethane (2b): Yellow liquid, Yield 62\%; ${ }^{1} \mathrm{H}$ NMR $\left(\mathrm{CDCl}_{3}\right)$ $\delta$ : 7.26-7.30 (m, 1H, Ph-5-H), 7.01 (d, 1H, J=7.2 Hz, Ph-6-H), 6.89-6.94 (m, 2H, Ph-2, 4-H), 6.85 (d, 1H, $\left.J=8.0 \mathrm{~Hz}, \mathrm{Ph}-5^{\prime}-\mathrm{H}\right), 6.72-6.77$ (m, 2H, Ph-2',6'-H), 3.95 (s, 2H, $\left.\mathrm{CH}_{2}\right), 3.89$ (s, 3H, $\mathrm{OCH}_{3}$ ), $3.87\left(\mathrm{~s}, 3 \mathrm{H}, \mathrm{OCH}_{3}\right) ;{ }^{13} \mathrm{C} \mathrm{NMR}\left(\mathrm{CDCl}_{3}\right) \delta: 164.2,161.8,149.0,147.6,144.1,144.0,132.8,129.9$, $129.8,124.4,121.0,115.8,115.5,113.1,112.9,112.2,111.3,55.9,55.8,41.2$; MS (ESI) $m / z: 247.0$ $\left([\mathrm{M}+\mathrm{H}]^{+}, 100\right)$.

4-fluoro-3',4'-dimethoxyl diphenylmethane (3b): Yellow liquid, Yield 40\%; ${ }^{1} \mathrm{H}$ NMR $\left(\mathrm{CDCl}_{3}\right)$

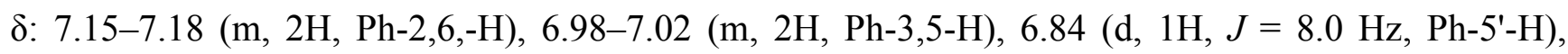
6.71-6.75 (m, 2H, Ph-2',6'-H), $3.93\left(\mathrm{~s}, 2 \mathrm{H}, \mathrm{CH}_{2}\right), 3.89\left(\mathrm{~s}, 3 \mathrm{H}, \mathrm{OCH}_{3}\right), 3.86\left(\mathrm{~s}, 3 \mathrm{H}, \mathrm{OCH}_{3}\right) ;{ }^{13} \mathrm{C}^{\mathrm{N} M R}$ $\left(\mathrm{CDCl}_{3}\right) \delta: 162.6,160.2,149.0,147.5,137.1,137.0,133.5,130.2,130.1,120.8,115.3,115.1,112.1$, 111.3, 55.9, 55.8, 40.6; MS (ESI) $m / z: 247.0\left([\mathrm{M}+\mathrm{H}]^{+}, 100\right)$.

2-iodo-3',4'-dimethoxyl diphenylmethane (4b): White powder, Yield 23\%, mp $48-49{ }^{\circ} \mathrm{C}$; ${ }^{1} \mathrm{H}$ NMR $\left(\mathrm{CDCl}_{3}\right) \delta: 7.90(\mathrm{dd}, J=1.2,8.0 \mathrm{~Hz}, 1 \mathrm{H}, \mathrm{Ph}-3-\mathrm{H}), 7.27-7.31(\mathrm{~m}, 1 \mathrm{H}, \mathrm{Ph}-5-\mathrm{H}), 7.13$ (dd, $J=1.2,7.6 \mathrm{~Hz}, 1 \mathrm{H}, \mathrm{Ph}-6-\mathrm{H}), 6.91-6.96$ (m, 1H, Ph-4-H), 6.82 (d, $J=8.0 \mathrm{~Hz}, 1 \mathrm{H}, \mathrm{Ph}-5$ '-H), 6.72-6.74

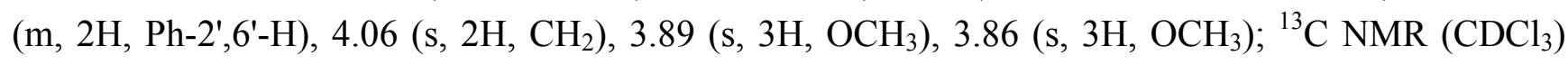
$\delta: 149.0,147.6,143.9,139.5,132.1,130.2,128.4,128.0,121.1,112.4,112.2,101.2,55.9,55.8,46.2$; MS (ESI) $m / z: 355.0\left([\mathrm{M}+\mathrm{H}]^{+}, 100\right)$.

\subsubsection{The Preparation of Compounds $\mathbf{1 c}-\mathbf{4 c}$}

2-fluoro-3',4'-dihydroxyl benzophenone (1c): Ten milliliters $\mathrm{BBr}_{3}$ solution $\left(\mathrm{BBr}_{3} / \mathrm{CH}_{2} \mathrm{Cl}_{2}, \mathrm{v} / \mathrm{v}, 1 / 9\right)$ was dropwisely added to a cooled $\left(-78{ }^{\circ} \mathrm{C}\right)$ solution of compound $1 \mathrm{a}(500 \mathrm{mg}, 1.92 \mathrm{mmol})$ in dried $\mathrm{CH}_{2} \mathrm{Cl}_{2}(20 \mathrm{~mL})$. The mixture was warmed to room temperature, stirred for $2 \mathrm{~h}$, and poured into ice-water $(50 \mathrm{~mL})$. The organic phase was separated. The water layer was extracted twice with ethyl acetate $(2 \times 20 \mathrm{~mL})$. The combined organics were washed with $20 \mathrm{~mL}$ water, dried over anhydrous $\mathrm{Na}_{2} \mathrm{SO}_{4}$ and concentrated via rotary evaporation. The crude product was purified by silica gel chromatography with ethyl acetate-petroleum ether $(1 / 4$, containing $1 \mathrm{~mL}$ acetic acid in $100 \mathrm{~mL}$ elution solvent) as eluent to afford compound $1 \mathrm{c}$ as a white powder in $53 \%$ yield. $\mathrm{mp} 149-150{ }^{\circ} \mathrm{C}$; ${ }^{1} \mathrm{H}$ NMR (DMSO- $\left.d_{6}\right) \delta:$ 7.58-7.63 (m, 1H, Ph-6-H), 7.46-7.50 (m, 1H, Ph-4-H), 7.32-7.38 (m, 2H, Ph-3,5-H), 7.26 (d, 1H, J = 1.6 Hz, Ph-2'-H), 7.12 (dd, 1H, $J=1.2,8.4$ Hz, Ph-6'-H), 6.87 (d, 1H, $J=8.4 \mathrm{~Hz}, \mathrm{Ph}-5$ '-H), 3.40 (br, 2H, Ph-OH); ${ }^{13} \mathrm{C}$ NMR (DMSO- $d_{6}$ ) $\delta: 191.5,160.4,158.0,152.1,145.8$, 
132.9, 132.8, 130.3, 130.2, 128.8, 128.1, 127.9, 125.1, 125.0, 123.9, 116.6, 116.4, 115.8; MS (ESI) m/z: 231.0 ([M-H] $\left.]^{-}, 100\right)$; HRMS (ESI): Calcd. for $\mathrm{C}_{13} \mathrm{H}_{9} \mathrm{~F}_{1} \mathrm{O}_{3}[\mathrm{M}-\mathrm{H}]^{-}: 231.0463$; Found: 231.0463.

Compounds $\mathbf{2 c - 4 c}$ were prepared in the similar manner as described for 1c.

3-fluoro-3',4'-dihydroxyl benzophenone (2c): White powder, Yield 48\%, mp 104-106 ${ }^{\circ} \mathrm{C}$; ${ }^{1} \mathrm{H}$ NMR (DMSO- $d_{6}$ ) $\delta: 7.44-7.59$ (m, 4H, Ph-2,4,5,6-H), 7.27 (d, 1H, J=2.0 Hz, Ph-2'-H), 7.15 (dd, $1 \mathrm{H}, J=2.0,8.0 \mathrm{~Hz}, \mathrm{Ph}-6$ '-H), 6.89 (d, 1H, $J=8.4 \mathrm{~Hz}, \mathrm{Ph}-5$ '-H), 5.00 (br, 2H, Ph-OH); ${ }^{13} \mathrm{C}$ NMR $\left(\mathrm{DMSO}_{6}\right) \quad \delta$ : 193.4, 163.4, 161.0, 151.5, 145.7, 141.8, 141.2, 141.1, 131.0, 130.9, 128.1, 125.6, 124.1, 117.3, 115.7; MS (ESI) $m / z: 231.0$ ([M - H] $]^{-}, 100$ ); HRMS (ESI): Calcd. for $\mathrm{C}_{13} \mathrm{H}_{9} \mathrm{~F}_{1} \mathrm{O}_{3}$ $[\mathrm{M}-\mathrm{H}]^{-}:$231.0463; Found: 231.0463 .

4-fluoro-3',4'-dihydroxyl benzophenone (3c): White powder, Yield 55\%, mp 155-157 ${ }^{\circ} \mathrm{C}$; ${ }^{1} \mathrm{H}$ NMR DMSO- $\left.d_{6}\right) \delta$ : 7.73-7.76 (m, 2H, Ph-2,6-H), 7.35-7.39 (m, 2H, Ph-3,5-H), $7.24(\mathrm{~d}, 1 \mathrm{H}$, $\left.J=2.0 \mathrm{~Hz}, \mathrm{Ph}-2^{\prime}-\mathrm{H}\right), 7.11$ (dd, 1H, $J=2.0,8.0 \mathrm{~Hz}, \mathrm{Ph}-6$ '-H), 6.87 (d, 1H, $J=8.0 \mathrm{~Hz}, \mathrm{Ph}-5$ '-H), 3.34 (br, 2H, Ph-OH); ${ }^{13} \mathrm{C}$ NMR (CD $\left.{ }_{3} \mathrm{OD}\right) \delta: 194.3,164.0,158.1,146.0,133.4,133.3,133.2,125.2$, 123.1, 118.0, 116.4, 116.2, 115.8; MS (ESI) $m / z: 231.0$ ([M - H] $\left.]^{-}, 100\right)$; HRMS (ESI): Calcd. for $\mathrm{C}_{13} \mathrm{H}_{9} \mathrm{~F}_{1} \mathrm{O}_{3}[\mathrm{M}-\mathrm{H}]^{-}: 231.0463$; Found: 231.0464 .

2-iodo-3',4'-dihydroxyl benzophenone (4c): White powder, Yield $60 \%$, mp $186-188{ }^{\circ} \mathrm{C} ;{ }^{1} \mathrm{H}$ NMR $\left(\mathrm{DMSO}_{6}\right) \delta$ : 7.89-7.95 (m, 1H, Ph-3-H), 7.46-7.54 (m, 1H, Ph-6-H), 7.16-7.31 (m, 2H, Ph-4,5-H), 7.00 (dd, $1 \mathrm{H}, J=1.6,8.4 \mathrm{~Hz}, \mathrm{Ph}-6$ '-H), 6.77 (s, 1H, Ph-2'-H), 6.41 (d, $\left.1 \mathrm{H}, J=8.4 \mathrm{~Hz}, \mathrm{Ph}-5^{\prime}-\mathrm{H}\right){ }^{13} \mathrm{C}$ NMR $\left(\mathrm{CD}_{3} \mathrm{OD}\right) \delta: 198.4,153.2,146.7,146.6,140.6,131.9,130.4,129.0,128.9,126.2,117.7,116.0$, 92.8; MS (ESI) $m / z$ : $339.0\left([\mathrm{M}-\mathrm{H}]^{-}, 100\right)$; HRMS (ESI): Calcd. for $\mathrm{C}_{13} \mathrm{H}_{9} \mathrm{I}_{1} \mathrm{O}_{3}[\mathrm{M}-\mathrm{H}]^{-}: 338.9524$; Found: 338.9514.

\subsubsection{The Preparation of Compounds $\mathbf{1 d}-\mathbf{4 d}$}

2-fluoro-3',4'-dihydroxyl diphenylmethane (1d): To a cooled $\left(-78{ }^{\circ} \mathrm{C}\right)$ solution of compound $\mathbf{1 b}(400$ $\mathrm{mg}, 1.63 \mathrm{mmol})$ in dried $\mathrm{CH}_{2} \mathrm{Cl}_{2}(5 \mathrm{~mL})$ was dropwisely added $5 \mathrm{~mL} \mathrm{BBr}$ solution $\left(\mathrm{BBr}_{3} / \mathrm{CH}_{2} \mathrm{Cl}_{2}, \mathrm{v} / \mathrm{v}\right.$, 1/9). The mixture was warmed to room temperature, stirred for $15 \mathrm{~min}$, and poured into ice-water (50 $\mathrm{mL})$. The organic layer was separated. The water layer was extracted twice with ethyl acetate $(2 \times 10 \mathrm{~mL})$. The combined organics were washed with $10 \mathrm{~mL}$ water and dried over anhydrous $\mathrm{Na}_{2} \mathrm{SO}_{4}$, then concentrated via rotary evaporation. The crude product was purified by silica gel chromatography with ethyl acetate/petroleum ether $(3 / 7$, containing $1 \mathrm{~mL}$ acetic acid in $100 \mathrm{~mL}$ elution solvent) as eluent to afford compound 1d as pale yellow powder in $40 \%$ yield. mp $91-92{ }^{\circ} \mathrm{C}$; ${ }^{1} \mathrm{H}$ NMR (DMSO-d $\left.d_{6}\right) \delta: 8.80$ (dd, $\left.1 \mathrm{H}, J=4.8,41.6 \mathrm{~Hz}, \mathrm{Ph}-6-\mathrm{H}\right), 7.10-7.27$ (m, 3H, Ph-3,4,5-H), 6.67 (d, 1H, $J=8.0$ Hz, Ph-6'-H), 6.59 (s, 1H, Ph-2'-H), 6.50 (d, 1H, J = 8.0 Hz, Ph-5'-H), 3.79 (s, 2H, $\mathrm{CH}_{2}$ ), 3.42 (br, 2H, Ph-OH); ${ }^{13} \mathrm{C}$ NMR (DMSO-d $) \delta: 162.0,159.5,145.6,144.1,131.7,131.6,131.1$, 129.1, 128.9, 128.5, 128.4, 124.8, 124.7, 119.7, 116.4, 116.0, 115.7, 115.5, 33.9; MS (ESI) m/z: 217.0 ([M-H] $\left.]^{-}, 100\right)$; HRMS (ESI): Calcd. for $\mathrm{C}_{13} \mathrm{H}_{11} \mathrm{~F}_{1} \mathrm{O}_{2}[\mathrm{M}-\mathrm{H}]^{-}:$217.0670; Found: 217.0672.

Compounds $\mathbf{2 d}-\mathbf{4 d}$ were prepared in the similar manner as described for $\mathbf{1 d}$.

3-fluoro-3',4'-dihydroxyl diphenylmethane (2d): Pale yellow powder, Yield 66\%, mp 66-68 ${ }^{\circ} \mathrm{C}$; ${ }^{1} \mathrm{H}$ NMR (DMSO- $\left.d_{6}\right) \quad \delta: 7.28-7.34(\mathrm{~m}, 1 \mathrm{H}, \mathrm{Ph}-5-\mathrm{H}), 6.99-7.04 \quad(\mathrm{~m}, 3 \mathrm{H}, \mathrm{Ph}-2,4,6-\mathrm{H}), 6.68$ 
(d, 1H, $\left.J=8.0 \mathrm{~Hz}, \mathrm{Ph}-5^{\prime}-\mathrm{H}\right), 6.60$ (d, 1H, $\left.J=2.0 \mathrm{~Hz}, \mathrm{Ph}-2^{\prime}-\mathrm{H}\right), 6.51$ (dd, 1H, $\left.J=2.0,8.0 \mathrm{HZ}, \mathrm{Ph}-6{ }^{\prime}-\mathrm{H}\right)$, 3.78 (s, 2H, $\mathrm{CH}_{2}$ ), 3.42 (br, 2H, Ph-OH); ${ }^{13} \mathrm{C}$ NMR (DMSO-d 6 ) $\delta: 163.9,161.5,145.6,145.5,145.4$, $144.1,131.9,130.6,130.5,125.1,119.9,116.6,116.0,115.7,115.5,113.1,112.9,40.5$; MS (ESI) $m / z: 217.0\left([\mathrm{M}-\mathrm{H}]^{-}, 100\right)$; HRMS (ESI): Calcd. for $\mathrm{C}_{13} \mathrm{H}_{11} \mathrm{~F}_{1} \mathrm{O}_{2}[\mathrm{M}-\mathrm{H}]^{-}:$217.0670; Found: 217.0672 .

4-fluoro-3',4'-dihydroxyl diphenylmethane (3d): White powder, Yield 59\%, mp 59-61 ${ }^{\circ} \mathrm{C}$; ${ }^{1} \mathrm{H}$ NMR (DMSO-d $)_{6}$ ): 7.32-7.86 (m, 2H, Ph-2,6-H), 6.95-7.23 (m, 2H, Ph-3,5-H), $6.66(\mathrm{~d}, 1 \mathrm{H}$, $\left.J=8.0 \mathrm{~Hz}, \mathrm{Ph}-5^{\prime}-\mathrm{H}\right), 6.55$ (d, 1H, $\left.J=2.0 \mathrm{~Hz}, \mathrm{Ph}-2^{\prime}-\mathrm{H}\right), 6.45$ (dd, 1H, $\left.J=2.0,8.0 \mathrm{~Hz}, \mathrm{Ph}-6{ }^{\prime}-\mathrm{H}\right)$, 3.88 (s, 2H, $\mathrm{CH}_{2}$ ), 3.38 (br, 2H, Ph-OH); ${ }^{13} \mathrm{C}$ NMR (DMSO- $d_{6}$ ) $\delta: 162.3,159.9,145.6,143.9,138.6$, 138.5, 132.5, 130.8, 130.7, 119.8, 116.5, 116.0, 115.5, 115.3, 40.0; MS (ESI) $\mathrm{m} / z: 217.0$ ([M - H] ${ }^{-}$, 100); HRMS (ESI): Calcd. for $\mathrm{C}_{13} \mathrm{H}_{11} \mathrm{~F}_{1} \mathrm{O}_{2}[\mathrm{M}-\mathrm{H}]^{-}: 217.0670$; Found: 217.0672.

2-iodo-3',4'-dihydroxyl diphenylmethane (4d): White powder, Yield 40\%, mp 130-132 ${ }^{\circ} \mathrm{C}$; ${ }^{1} \mathrm{H}$ NMR $\left(\mathrm{DMSO}-d_{6}\right) \delta: 7.86(\mathrm{dd}, 1 \mathrm{H}, J=1.2,8.0 \mathrm{~Hz}, \mathrm{Ph}-3-\mathrm{H}), 7.36$ (m, 1H, Ph-5-H), 7.23 (dd, 1H, $J=1.6,7.6 \mathrm{~Hz}, \mathrm{Ph}-6-\mathrm{H}), 6.99$ (m, 1H, Ph-4-H), 6.66 (d, 1H, $J=8.0 \mathrm{~Hz}, \mathrm{Ph}-5$ '-H), 6.55 (d, 1H, $J=2.0 \mathrm{~Hz}, \mathrm{Ph}-2$ '-H), 6.47 (dd, 1H, $J=2.0,8.0 \mathrm{~Hz}, \mathrm{Ph}-6$ '-H), 3.88 (s, 2H, $\mathrm{CH}_{2}$ ), 3.38 (br, 2H, Ph-OH);

${ }^{13} \mathrm{C}$ NMR (DMSO- $d_{6}$ ) $\delta: 144.4,139.6,130.9,130.8,128.9,128.7,120.0,116.5,116.4,116.0,115.9$, 101.8, 45.3; MS (ESI) $m / z$ : 325.0 ([M - H] $]^{-}$, 100); HRMS (ESI): Calcd. for $\mathrm{C}_{13} \mathrm{H}_{11} \mathrm{I}_{1} \mathrm{O}_{2}$ $[\mathrm{M}-\mathrm{H}]^{-}:$324.9731; Found: 324.9726.

\subsection{Pharmacology}

After removal of the male mouse (SD) meninges, the brain was weighted and homogenized with a

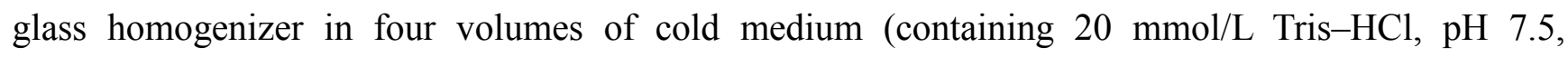
$0.25 \mathrm{~mol} / \mathrm{L}$ sucrose, $2 \mathrm{mmol} / \mathrm{L}$ DDT, $2 \mathrm{mmol} / \mathrm{L}$ EDTA, $2 \mathrm{mmol} / \mathrm{L} \mathrm{Na}_{3} \mathrm{VO}_{4}, 1 \mathrm{mmol} / \mathrm{L} \mathrm{DMSF}, 215 \mathrm{mg} / \mathrm{L}$ aprotinin, $1 \mathrm{mg} / \mathrm{L}$ PTIFtatin, $5 \mathrm{mg} / \mathrm{L}$ leupeptin) at high speed. The mixture was centrifuged for $10 \mathrm{~min}$ at $1000 \times \mathrm{g}$ at $4{ }^{\circ} \mathrm{C}$; the supernatant was collected and re-centrifuged for $10 \mathrm{~min}$ at $10,000 \times \mathrm{g}$ at $4{ }^{\circ} \mathrm{C}$ to obtain the target supernatant. The target supernatant that contained cytoplasmic tyrosine kinase was collected, separately packed and stored at $-70{ }^{\circ} \mathrm{C}$.

PTK activity was determined by the ELISA method. In brief, the concentrations of PTKs used to construct calibration curves were as follows: 600, 500, 341, 200 and $100 \times 10^{-7} \mathrm{U} / \mathrm{mL}$ for PTK. $100 \mu \mathrm{L}$ of $20 \mathrm{mg} / \mathrm{L}$ PGT (Sigma Aldrich) in $20 \mathrm{mmol} / \mathrm{L}$ PBS solution was added to 96-well microtiter plates at $37^{\circ} \mathrm{C}$ overnight. After removing excess substrate solution, PBS-Tween 20 (PBST) was used to wash the wells one time, which were dried for $2 \mathrm{~h}$ at $37{ }^{\circ} \mathrm{C}$ and kept at $4{ }^{\circ} \mathrm{C}$. Subsequently, $50 \mu \mathrm{L}$ of the above PTK extraction (50 mmol/L HEPES, pH 7.4, $20 \mathrm{mmol} / \mathrm{L} \mathrm{MgCl}_{2}, 0.1 \mathrm{mmol} / \mathrm{L} \mathrm{MnCl}_{2}$, $0.2 \mathrm{mmol} / \mathrm{L} \mathrm{Na}_{3} \mathrm{VO}_{4}, 0.6 \mathrm{mmol} / \mathrm{L}$ ATP) was added to the 96 -well plates. Then, a certain concentration of the tested compounds $(10 \mu \mathrm{L})$ and tyrosine kinase tissue extract solution were incubated at $37^{\circ} \mathrm{C}$ for $1 \mathrm{~h}$. The plate was washed three times with PBST at the end of the treatment, and $100 \mu \mathrm{L}$ of the diluted horseradish-peroxidase-labeled mouse anti-phosphotyrosine monoclonal antibody $\operatorname{IgG}_{2 \mathrm{bk}}$ (Sigma Aldrich) was added to each well, and incubated at $37^{\circ} \mathrm{C}$ for $30 \mathrm{~min}$. After removal of the antibody complex, and then washing three times with PBST, $100 \mu \mathrm{L}$ freshly prepared TMB horseradish peroxidase color development solution (Beijing 4A Biotech Co., Ltd, China) was added and protected 
from light for $10 \mathrm{~min}$. The reaction was terminated by addition of $100 \mu \mathrm{L} /$ well $1 \mathrm{~N}$ sulfuric acid. Absorbance was measured at $450 \mathrm{~nm}$ in a microplate reader (SpectraMax M5) [4].

\section{Conclusions}

In this study, we prepared a series of new benzophenone and diphenylmethane halophenol derivatives and investigated the influence of the linker, substituted groups, number and positions of halogen atoms on PTK inhibitory activities.

All of the chlorophenols exhibited strong activities, and the substituted position of the chloro atom also markedly affected the activity. Unfortunately, all of the fluoro- and iodo- functionalized compounds were inactive. Our findings confirmed that the hydroxyls and halogens (chloro or bromo) seem to be essential to the activity, and the chloro atom and methylene group play a crucial role in the activity. Hence, these compounds with high activities represent a new paradigm for halophenols and appear to offer great potential as new PTK inhibitors. The results also gave a relatively full recognition of the SARs, and provided a foundation for further structural optimization of the halophenols in the search for suitable clinical candidates.

\section{Conflict of Interest}

The authors have declared no conflict of interest.

\section{Acknowledgments}

We would like to thank Guanhua Du, Lianhua Fang, Guorong He, for their help with the in vitro assay of the compounds. This work was financially supported by the "Innovative Drugs Development" State Key Science and Technology Projects of China (No.2009ZX09302-003), from the National "863" Program of China (No. 2011), from the State Key laboratory of Natural and Biomimetic Drugs, Peking University (NO.20080210) and Shanxi Foundation for overseas returned (2008-51), by the Program for the Top Science and Technology Innovation Teams of Higher Learning Institutions of Shanxi Province (2011), by the Program for the Top Young and Middle-aged Innovative Talents of Higher Institutions of Shanxi Province and by High School Technology Fund Projects of Shanxi Province (200811011).

\section{References}

1. Bolla, M.; Rostaing-Puissant, B.; Bottari, S.P.; Chedin, M.; Marron-Charriere, J.; Colonna, M.; Berland, E.; Chambaz, E. Protein tyrosine kinase activity in 350 T1/T2, N0/N1 breast cancer. Preliminary results. Breast Cancer Res. Treat. 1996, 39, 327-334.

2. Hirabayashi, A.; Mukaiyama, H.; Kobayashi, H.; Shiohara, H.; Nakayama, S.; Ozawa, M.; Tsuji, E.; Miyazawa, K.; Misawa, K.; Ohnota, H.; et al. Structure-activity relationship studies of imidazo[1,2-c]pyrimidine derivatives as potent and orally effective Syk family kinases inhibitors. Bioorg. Med. Chem. 2008, 16, 9247-9260. 
3. Jung, K.J.; Lee, E.K.; Yu, B.P.; Chung, H.Y. Significance of protein tyrosine kinase/protein tyrosine phosphatase balance in the regulation of NF- $\kappa B$ signaling in the inflammatory process and aging. Free Radic. Biol. Med. 2009, 47, 983-991.

4. Shi, L.; Feng, X.E.; Cui, J.R.; Fang, L.H.; Du, G.H.; Li, Q.S. Synthesis and biological activity of flavanone derivatives. Bioorg. Med. Chem. Lett. 2010, 20, 5466-5468.

5. Hori, H.; Nagasawa, H.; Uto, Y.; Ohkura, K.; Kirk, K.L.; Uehara, Y.; Shimamura, M. Design of hypoxia-targeting protein tyrosine kinase inhibitor using an innovative pharmacophore 2-methylene-4-cyclopentene-1,3-dione. Biochim. Biophys. Acta 2004, 1697, 29-38.

6. Liechti, C.; Sequin, U.; Bold, G.; Furet, P.; Meyer, T.; Traxler, P. Salicylanilides as inhibitors of the protein tyrosine kinase epidermal growth factor receptor. Eur. J. Med. Chem. 2004, 39, 11-26.

7. Li, H.Q.; Zhu, T.T.; Yan, T.; Luo, Y.; Zhu, H.L. Design, synthesis and structure-activity relationships of antiproliferative 1,3-disubstituted urea derivatives. Eur. J. Med. Chem. 2009, 44, 453-459.

8. Kilic, Z.; Isgor, Y.G.; Olgen, S. Synthesis and pp60 $60^{\mathrm{c}-S r c}$ tyrosine kinase inhibitory activities of novel indole-3-imine and amine derivatives substituted at N1 and C5. Arch. Pharm. Chem. Life Sci. 2009, 342, 333-343.

9. Olgen, S.; Isgor, Y.G.; Coban, T. Synthesis and activity of novel 5-substituted pyrrolo[2,3-d]pyrimidine analogues as pp60 $0^{\mathrm{c}-S r c}$ tyrosine kinase inhibitors. Arch. Pharm. Chem. Life Sci. 2008, 341, 113-120.

10. Mazitschek, R.; Giannis, A. Inhibitors of angiogenesis and cancer-related receptor tyrosine kinases. Curr. Opin. Chem. Biol. 2004, 8, 432-441.

11. Li, J.; Guo, S.J.; Su, H.; Han, L.J.; Shi, D.Y. Total synthesis of bis-(2,3-dibromo-4,5dihydroxyphenyl)-methane as potent PTP1B inhibitor. Chin. Chem. Lett. 2008, 19, 1290-1292.

12. Li, K.; Li, X.M.; Ji, N.Y.; Gloer, J.B.; Wang, B.G. Urceolatin, a structurally unique bromophenol from Polysiphonia urceolata. Bioorg. Med. Chem. 2007, 15, 6627-6631.

13. Duan, X.J.; Li, X.M.; Wang, B.G. Highly brominated mono- and bis-phenols from the marine red alga symphyocladia latiuscula with radical-scavenging activity. J. Nat. Prod. 2007, 70, 1210-1213.

14. Shi, D.Y.; Li, J.; Guo, S.J.; Han, L.J. Antithrombotic effect of bromophenol, the alga-derived thrombin inhibitor. J. Biotechnol. 2008, 136, S579.

15. Popplewell, W.L.; Northcote, P.T. Colensolide A: A new nitrogenous bromophenol from the New Zealand marine red alga Osmundaria colensoi. Tetrahedron Lett. 2009, 50, 6814-6817.

16. Oh, K.B.; Lee, J.H.; Lee, J.W.; Yoon, K.M.; Chung, S.C.; Jeon, H.B.; Shin, J.; Lee, H.S. Synthesis and antimicrobial activities of halogenated bis(hydroxyphenyl)methanes. Bioorg. Med. Chem. Lett. 2009, 19, 945-948.

17. Wiemer, D.F.; Idler, D.D.; Fenical, W. Vidalols A and B, new anti-inflammatory bromophenols from the Caribbean marine alga Vidalia obtusiloba. Experientia 1991, 47, 851-853.

18. Wang, W.; Okada, Y.; Shi, H.B.; Wang, Y.Q.; Okuyama, T. Structures and aldose reductase inhibitory effects of bromophenols from the red alga Symphyocladia latiuscula. J. Nat. Prod. 2005, 68, 620-622.

19. Xu, X.L.; Song, F.H.; Wang, S.J.; Li, S.; Fan, X.; Zhao, J.L.; Yang, Y.C.; Shang, S.Q; Yang, L.; Shi, J.G. Dibenzyl bromophenols with diverse dimerization patterns from the brown alga Leathesia nana. J. Nat. Prod. 2004, 67, 1661-1666. 
20. Kurata, K.; Taniguchii, K.; Takashima, K.; Hayashi, I.; Suzuki, M. Feeding-deterrent bromophenols from Odonthalia corymbifera. Phytochemistry 1997, 45, 485-487.

21. Shi, D.Y.; Li, J.; Guo, S.J.; Su, H.; Fan, X. The antitumor effect of bromophenol derivatives in vitro and Leathesia nana extract in vivo. Chin. J. Oceanol. Limnol. 2009, 27, 277-282.

22. Zhao, W.Y.; Feng, X.E.; Ban, S.R.; Lin, W.H.; Li, Q.S. Synthesis and biological activity of halophenols as potent antioxidant and cytoprotective agents. Bioorg. Med. Chem. Lett. 2010, 20, 4132-4134.

23. Jager, W.; Winter, O.; Halper, B.; Salamon, A.; Sartori, M.; Gajdzik, L.; Hamilton, G.; Theyer, G.; Graf, J.; Thalhammer, T. Modulation of liver canalicular transport processes by the tyrosine- kinase inhibitor genistein: Implications of genistein metabolism in the rat. Hepatology 1997, 26, 1467-1476.

24. Majewska, E.; Paleolog, E.; Baj, Z.; Kralisz, U.; Feldmann, M.; Tchorzewski, H. Role of tyrosine kinase enzymes in TNF-a and IL-1 induced expression of ICAM-1 and VCAM-1 on human umbilical vein endothelial cells. Scand. J. Immunol. 1997, 45, 385-392.

25. Han, X.J.; Civiello, R.L. Mercer, S.E.; Macor, J.E.; Dubowchik, G.M. Synthesis of aza and fluorine-substituted 3-(piperidin-4-yl)-4,5-dihydro-1H-benzo[ $d][1,3]$ diazepin-2(3H)-ones. Tetrahedron Lett. 2009, 50, 386-388.

26. Xue, J.; Kumar, V.; Khaja, S.D.; Chandrasekaran, E.V.; Locke, R.D.; Matta, K.L. Syntheses of fluorine-containing mucin core 2 /core 6 structures using novel fluorinated glucosaminyl donors. Tetrahedron 2009, 65, 8325-8335.

27. Tsirkone, V.G.; Tsoukala, E.; Lamprakis, C.; Manta, S.; Hayes, J.M.; Skamnaki, V.T.; Drakou, C.; Zographos, S.E.; Komiotis, D.; Leonidas, D.D. 1-(3-Deoxy-3-fluoro- $\beta$-D-glucopyranosyl) pyrimidine derivatives as inhibitors of glycogen phosphorylase b: Kinetic, crystallographic and modelling studies. Bioorg. Med. Chem. 2010, 18, 3413-3425.

28. Fehér, C.; Urbán, B.; Urge, L.; Darvas, F.; Bakos, J.; Skoda-Foldes, R. Facile synthesis of 6-iodo-2,2'-dipivaloyloxy-1,1'-binaphthyl, a key intermediate of high reactivity for selective palladium-catalyzed monofunctionalization of the 1,1'-binaphthalene core. Tetrahedron Lett. 2010, 51, 3629-3632.

29. Castro, M.D.; Marzabadi, C.H. Preparation and reactions of iodo sugars. Tetrahedron 2010, 66, 3395-3404.

30. Mphahlele, M.J.; Lesenyeho, L.G.. ; Makelane, H.R. Synthesis of 1H-pyrrolo[3,2-c]quinoline derivatives via palladium-catalyzed heteroannulation of 2-aryl-3-iodo-4-(phenylamino)quinolines and 4-(N,N-allylphenylamino)-2-aryl-3-iodoquinolines. Tetrahedron 2010, 66, 6040-6046.

(C) 2011 by the authors; licensee MDPI, Basel, Switzerland. This article is an open access article distributed under the terms and conditions of the Creative Commons Attribution license (http://creativecommons.org/licenses/by/3.0/). 